\title{
Ranking of Sustainability Indicators for Assessment of the New Housing Development Projects: Case of the Baltic States
}

\author{
Laura Tupenaite ${ }^{1, *}$, Irene Lill ${ }^{2}$, Ineta Geipele ${ }^{3}$ and Jurga Naimaviciene ${ }^{4}$ \\ 1 Department of Construction Management and Real Estate, Faculty of Civil Engineering, Vilnius Gediminas \\ Technical University, Saulètekio al. 11, LT-10223 Vilnius, Lithuania \\ 2 Department of Civil Engineering and Architecture, School of Engineering, Tallinn University of Technology, \\ Ehitajate tee 5, 19086 Tallinn, Estonia; irene.lill@ttu.ee \\ 3 Department of Civil Construction and Real Estate Management, Riga Technical University, 6 Kalnciema Str., \\ Riga LV-1048, Latvia; ineta.geipele@rtu.lv \\ 4 Department of Construction Management and Real Estate, Faculty of Civil Engineering, Vilnius Gediminas \\ Technical University, Sauletekio al. 11, LT-10223 Vilnius, Lithuania; jurga.naimaviciene@vgtu.lt \\ * Correspondence: laura.tupenaite@vgtu.lt; Tel.: +370-65-280-529
}

Received: 24 August 2017; Accepted: 2 October 2017; Published: 13 October 2017

\begin{abstract}
Sustainable development is inconceivable without healthy real estate market. A housing project can be regarded as sustainable only when all the dimensions of sustainability (environmental, economic, and social) are dealt with. There has been an increased interest in using sustainability indicators for evaluating the impacts of the new development projects. Although international literature is rich in sustainability assessments, there are no tools developed for assessment of new residential projects in the specific context of the Baltic States. Therefore, the aim of this article is to fill this gap and to propose an integrated, hierarchically structured system of sustainability indicators to be used for assessment of the new housing development projects. This aim is achieved through accomplishing three objectives. First, based on a review of literature related to assessing building project performance and sustainable development in construction, the paper proposes an original hierarchically structured system of sustainability indicators suitable for the Baltic context. Second, based on a survey of experts, significances of criteria are estimated by the Analytic Hierarchy Process (AHP) method. Finally, paper proposes recommendations to government authorities and real estate developers as to how to enhance the performance of new residential projects according to the principles of sustainability.
\end{abstract}

Keywords: sustainability indicators; housing development; new projects; AHP; ranking

\section{Introduction}

In Brundtland's report [1], sustainable development is "development that meets the needs of the present without compromising the ability of future generations to meet their own needs". In general, sustainable development encompasses three interacting dimensions: environmental, economic and social.

It is widely accepted that the construction sector is one of the main contributors to sustainable development, and its role in encouraging environmental protection, economic growth, and social progress is undeniable [2]. Moreover, as Holmstedt et al. [3] claim, "urban sustainable development is today seen as one of the keys towards unlocking the quest for a sustainable world".

One of the key sectors in achieving sustainable development is residential construction. Traditionally, housing development projects had mainly concentrated on the technical and financial feasibility. Recently, attitudes have changed. For instance, research by Zhang et al. [4] revealed that 
housing developers believe that the application of green technologies can contribute to reputation gaining, reduction in construction and operation cost, receiving favourable land prices, and more channels available for financing. As Hwang and Tan [5] note, "the demand for green buildings is expected to increase along with public awareness of environmental issues and advantages of sustainable construction as a result of improved R\&D in green products and technologies".

From a social perspective, housing not only offers accommodation but also gives a sense of a secure future and strengthens local communities [6]. From an economic perspective, houses are among the major investments that people make in their lifetimes [7]. However, from an environmental perspective, the housing sector in the European Union uses $40 \%$ of total final energy consumed (of which heating and cooling accounts around $70 \%$ ) and releases about $36 \%$ of total $\mathrm{CO}_{2}$ emissions [8]. Therefore, a housing project can be regarded as sustainable only when all three dimensions of sustainability—environmental, economic and social—are taken into account. The various issues of sustainability are interrelated, and the interaction of a building with its environment has important ramifications [9]. A complete sustainability understanding also necessitates the consideration of environmental and ecological indicators related to the use of natural resources along with the ones associated with the society and economy as a whole [10]. Common considerations include those of the use of environmental friendly materials and water, reduction of energy consumption, ensuring healthy and comfortable indoor climate, reduction of pollution, cohesion of community, ensuring housing affordability, etc. Moreover, as was noticed by Capolongo et al. [11], "it is becoming increasingly important to strengthen synergies and multidisciplinary collaborations to achieve shared performance indications and to make a systematic review of the regulatory tools to protect public health".

According to Mateus and Bragança [9] and Zhang et al. [4,12], developing and using building sustainability measurement and benchmarking methods are one of the solutions that promote a more sustainable built environment.

Although international literature is rich in residential projects' sustainability assessments, studies in the context of the Baltic States are very limited. There are only few studies to be mentioned. In Lithuania, Viteikiene and Zavadskas [13] used COPRAS (Complex Proportional Assessment) method to rank residential areas according to the overall sustainability performance, which was indexed based on 22 indicators related to sustainable development. More recently, Zavadskas et al. [14] assessed 21 neighbourhoods in Vilnius, Lithuania in the context of a healthy and safe built environment in view of the principles of sustainable development. In the study by Brizga [15], sustainable development integration in Latvia's environmental policy, focusing on assessment and analysis of normative, organizational and procedural policy integration instruments was analysed. Author concluded that there is no formal policy integration process in place and main integration barriers are lack of integration procedures, conflicting interests of stakeholders and organizational fragmentation. Zilans and Abolina [16] studied a methodology for assessing urban sustainability according to Aalborg commitments in Riga, Latvia. Geipele et al. [17] analysed interaction of socio-economic factors and real estate market in the context of sustainable urban development in Latvia comparing to other Baltic States. Nuuter et al. [18] used COPRAS method for comparison of housing market sustainability in European countries, including Estonia, Lithuania and Latvia.

Sustainable development is a specific interest of Lithuanian Real Estate Developers Association. Each year a sustainable development competition is organized [19]. Lithuania's real estate developers are encouraged to take an active part in the contest of the best projects, with a strong focus on the ideas of sustainable development. The projects are evaluated by experts according to eight criteria: adequateness of the object to sustainable urban development aims (renovation of existing residential areas or buildings; multi-functionality; access to public transport and other public infrastructure; and adjustment of environmental, economic and social tasks); architectural, urban and building quality; respect to nature and cultural heritage values; energy saving according to 2009/28/ES, 2010/31/ES, and 2012/27/ES directives; innovativeness and non-traditional solutions; use of local production for the project; and organization's image in society and business ethics. 
Latvian Sustainable Building Council (LSBC) [20] was founded at the end of 2010 as a private sector initiative to increase the sustainability of the built environment in Latvia. It provides practical support to sustainable project development. With this aim in mind, LSBC has been instrumental in providing the local market with a set of sustainable building criteria for new commercial developments (buildings)-An adapted version of BREEAM (BRE Environmental Assessment Method).

The Estonian Green Building Council (Eesti GBC) [21] promotes the highest quality levels in planning, design, construction and operation for energy and real estate. Its members provide excellence, expertise and outstanding professionalism. Eesti GBC encourages certification of the buildings according to the BREEAM and LEED (Leadership in Energy and Environmental Design) standards.

In summary, there are sustainability promotion initiatives in the Baltic States and some of the previous research investigations have examined sustainability issues, however, to the best knowledge of authors, none of the previous studies presented the sustainability assessment framework for the new residential projects. This publication aims to fill this gap and to propose a novel integrated, hierarchically structured system of sustainability indicators to be used for assessment of the new housing projects in the Baltic States.

\section{Literature Review}

Since the Rio Summit, many sustainability assessment indicators and frameworks have been formulated to provide sustainability-related decision-making processes, and have been widespread internationally [22]. The construction industry has a long history in developing and using of indicators, alongside of many general efforts to develop sustainable development indicators [23]. However, social and economic indicators are often neglected in the literature $[2,9,24]$ and, as Berardi [25] notes, the social aspect is the most ignored dimension of sustainability.

There are many methods developed for sustainability assessment (e.g., LEED in the USA, BREEAM in the UK, CASBEE (Comprehensive Assessment System for Built Environment Efficiency) in Japan, and GBTool (Green Building Tool) in Canada) and Life-cycle-based tools (e.g., Eco-Quantum in Netherlands, EcoEffect in Sweden, ENVEST (Environmental impact analysis for buildings) in the UK, BEES (Building for Environmental and Economic Sustainability) in the USA, ATHENA (Athena Sustainable Materials Institute Life Cycle Assessment Tools) in Canada, and LCA (Lifecycle Assessment) House in Finland); however, "usually these methods ignore the economic and social aspects, and sustainable criteria are not prioritized for decision making facilitation" [24].

On the other hand, academics have developed numerous construction project evaluation methods, indicators and models for assessment of sustainability. Some of the studies deal with the housing projects. Ali and Al Nsairat [26] suggested green building assessment tool (SABA Green Building Rating System) for the Jordanian context. Alwaer and Clements-Croome [27] introduced a consensus-based model (Sustainable Built Environment Tool (SuBETool)) for the sustainability assessment of intelligent buildings.

Study by Bragança et al. [28] intended to be the basis for the future development of an advanced residential building sustainability rating tool, especially suitable for Portuguese traditions, climate, society, and national standards. Afterwards, Mateus and Bragança [9] presented an innovative approach (SBToolPT-H) to assess the sustainability of existing, new and renovated residential buildings in urban areas, specifically in the Portuguese context. Bakar et al. [29] presented A Comprehensive Assessment System for Sustainable Housing (CASSH) for measuring sustainability in housing development to suit the Malaysian context.

Wallbaum et al. [23] proposed indicator based sustainability assessment tool for affordable housing construction technologies. Turcu [30] used a set of 26 sustainability indicators for evaluating social housing regeneration projects. Mulliner et al. [31] assessed sustainable housing affordability by COPRAS method in Liverpool (the UK).

A survey performed by Chandratilake and Dias [32] in Sri Lanka aimed to establish relative weights for various domains and aspects for a rating system in national context. Analytic Hierarchy 
Process (AHP) method was used, six domains (site, energy efficiency, water efficiency, materials, indoor environmental quality and waste and pollution) were considered. Alyami et al. [33] developed the sustainable building assessment scheme for Saudi Arabia by using Delphi consultation approach. Mardani et al. [34] presented a hierarchical framework for evaluating and ranking the important key energy-saving technologies and solutions in the 10 biggest Iranian hotels through integrating fuzzy set theory, as well as qualitative and quantitative approaches. Higham and Stephenson [35] proposed 17 sustainability factors that are categorised into standard, environmental, economic and social factors.

Yu et al. [36] developed an assessment method for green store buildings in China. The Expert Group Decision AHP method was used. The indicator system of the green store building rating included seven categories (landscape, energy efficiency, water efficiency, material and resources, indoor environment, construction management, and operation management).

Nilashi et al. [37] proposed a knowledge-based expert system to assess the performance level of a green building based on assessment criteria of building rating systems. AHP and fuzzy logic was applied for development of the system. Study by Preval et al. [38] evaluated the impact of the special housing areas on measures of environmental sustainability in New Zealand.

Abdul-Rahman et al. [24] developed a Fuzzy Weighted Hierarchy for Triquetrous Sustainability (FWH-TS) for integrating and ranking sustainability criteria for housing, in total 52 environmental, economic and social indicators were used.

Burdova and Vilcekova [39] presented a new Building Environmental Assessment System (BEAS) which was developed in the Slovak Republic. System encompasses 52 environmental, economic and social indicators that represent Slovak standards and rules. Kang et al. [40] proposed sustainable building assessment tool for project decision makers in the Republic of Korea.

Review of the academic research reveals that different sustainability indicators and systems are used for assessment of residential projects' sustainability in different countries. As noted by Mateus and Bragança [9], Ali and Al Nsairat [26], Bakar et al. [29], Chandratilake and Dias [32], and Alyami et al. [33], particular indicators and their significances are highly dependent on the environmental, social and economic contexts of their use; therefore, most authors aim to develop national sustainability assessment systems. Academics also disagree on the nature and extent of the indicators to be measured, and "there exist significant conflicts between the models proposed regarding their detail, the measurement and evaluation approach, and the nature of their overarching features, so a suitable structured framework to assist project teams involved in the delivery of sustainable building projects is lacking" [41].

\section{Materials and Methods}

The methodology of research is presented in Figure 1. It is based on the Analytic Hierarchy Process (AHP) method by Saaty [42]. Literature review revealed that AHP is a useful method for weighting sustainability indicators as: (1) AHP has the characteristics of a hierarchical structure, which is aligned with the structures of most sustainability frameworks and makes the process easy to comprehend for stakeholders; (2) is simple and flexible; (3) provides a consistent verification operation; and (4) this method can be used with both qualitative and quantitative data [43,44].

AHP method was proven as efficient, and is widely used by many authors for different sustainability-related tasks' solutions (see e.g., [24,32,36,37,45-56]. Moreover, approximately 3000 papers concerning multi-criteria decision analysis (MCDA) in the environmental field were identified by Cegan et al. [57]. The results showed a linear growth in the share of MCDA papers in environmental science across all application areas and reveal that AHP/Analytic network process (ANP) and MAUT/MAVT are the most frequently mentioned MCDA methods in the literature. Similar findings were provided in an overview of the application of MCDM techniques and approaches in the field of sustainable and renewable energy. It was found that AHP/fuzzy AHP and integrated methods were ranked as the first rank, with 14 papers out of 54 papers published from 2003 to 2015 in more than 20 high-ranking journals [58]. 


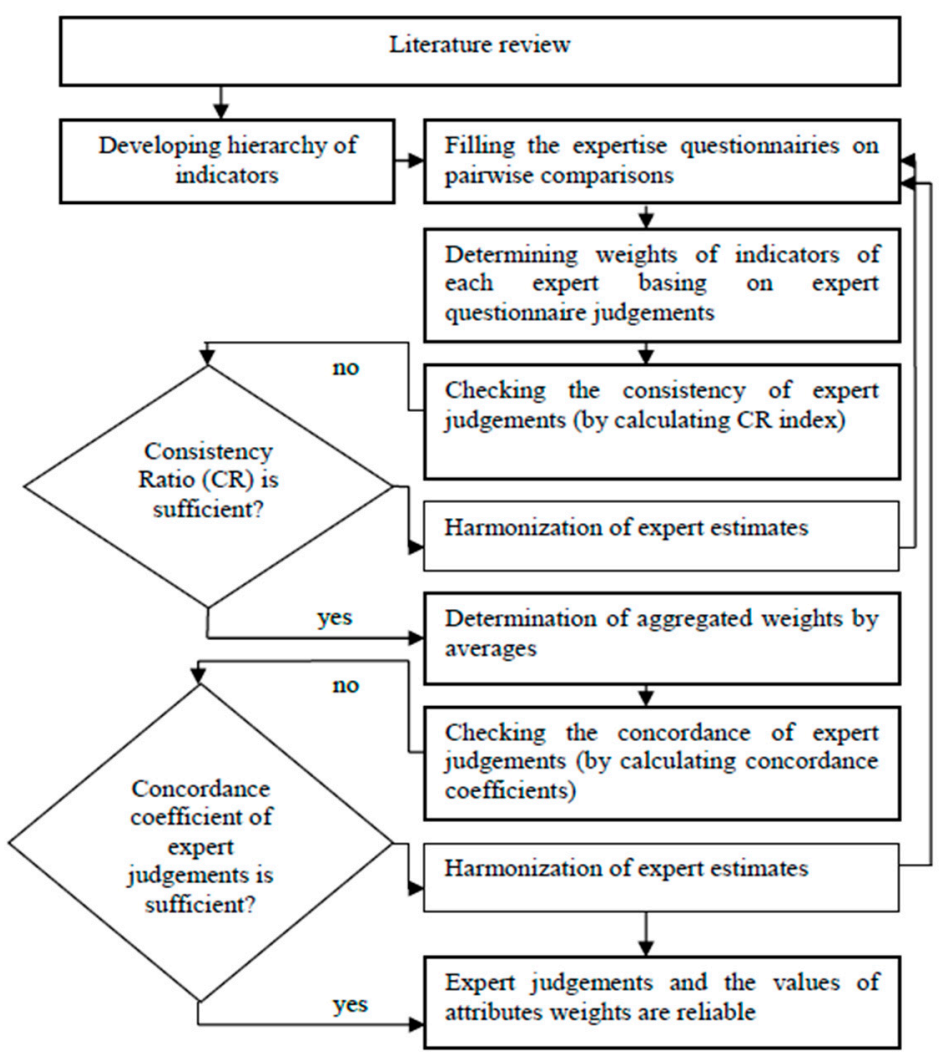

Figure 1. Research methodology.

According the AHP method, when structuring the hierarchy, the overall objective is on the top, followed by less important criteria. All of the criteria can be satisfied, achieved by different alternatives. To be able to rank these alternatives against criteria of different importance, individual weighting factors must be assigned. That requires creation of a pair-wise comparison matrix [43]. Alternatives are compared in pairs, and the results are organised into a scale of 1-9 from equally important (value of 1 ) to extremely most important (value of 9) (see Table 1).

Table 1. Saaty's scale of measurement in pair-wise comparison [42].

\begin{tabular}{ccl}
\hline Intensity of Importance & \multicolumn{1}{c}{ Definition } & \multicolumn{1}{c}{ Explanation } \\
\hline 1 & Equal importance & Two indicators contribute equally to the objective \\
\hline 3 & Moderate importance & Experience and judgment slightly favour one to another \\
\hline 7 & Strong importance & Experience and judgment strongly favour one to another \\
\hline 9 & Very strong importance & $\begin{array}{l}\text { An indicator is strongly favoured and its dominance is } \\
\text { demonstrated in practice }\end{array}$ \\
\hline $2,4,6,8$ & Intermediate values & $\begin{array}{l}\text { The importance of one over another affirmed on the highest } \\
\text { possible order }\end{array}$ \\
\hline Reciprocals of above non-zero numbers & $\begin{array}{l}\text { Uf indicator } i \text { has one of the above non-zero numbers assigned to it } \\
\text { when compared with indicator } j, \text { then } j \text { has the reciprocal value } \\
\text { when compared with } i\end{array}$ \\
\hline
\end{tabular}

Judgment matrices, filled by experts, are used for the calculations of determinants' significances, according to the formulas [42]:

$$
q_{i}=\frac{\left(\prod_{j=1}^{m} c_{i j}\right)^{\frac{1}{m}}}{\sum_{k=1}^{m}\left(\prod_{j=1}^{m} c_{k j}\right)^{\frac{1}{m}}},
$$


and

$$
\lambda_{\text {max }}=\sum_{i=1}^{m}\left\{\left(\sum_{j=1}^{m} c_{i j}\right) \times q_{i}\right\},
$$

where $k$ is the number of experts; $m$ is the number of indicators; $c_{i}$ is the $i$ th determinant; $q_{i}$ is the significance (weight) of the $i$ th indicator; and $\lambda$ is the eigenvalue.

The consistency ratio $(C R)$ of each matrix was checked according to the formula [42]:

$$
C R=\frac{C I}{R I},
$$

where $R I$ is the random consistency index and $C I$ is the consistency index calculated as follows [42]:

$$
C I=\frac{\left(\lambda_{\max }-m\right)}{(m-1)} .
$$

Saaty [42] has set the acceptable $C R$ values for the different matrices' sizes: the $C R$ value is 0.05 for a 3-by-3 matrix; 0.08 for a 4 -by-4 matrix; and 0.1 for larger matrices.

Further significances provided by each of the experts are aggregated and assumed as distribution and the averages of these distributions are calculated in order to determine the final significances of indicators.

Reliability of the data is expressed by the coefficient of concordance (agreement) of the experts' opinions by describing the extent to proximity of individual views. For this purpose, Kendall's coefficient of concordance [59] is used:

$$
W=\frac{12 S}{r^{2}\left(m^{3}-m\right)-r \sum_{k=1}^{r} T_{k}} ; W \in[0 ; 1],
$$

where $S$ is the total square deviation of the rankings of each attribute; $T_{k}$ is the index of reiterated ranks in the $r$ rank, $k$ is the number of respondents and $m$ is the number of indicators.

However, the calculated value $W$ is stochastic; therefore, the significance of the concordance coefficient should be calculated. Kendall [59] has proven that, when $m>7$, the significance of the concordance coefficient can be calculated by $\chi^{2}$ criterion which has a distribution with degree of freedom $v=m-1$. It has been proven that, if the calculated value $\chi^{2}$ is larger than the critical tabular value $\chi_{c r i t}^{2}$ for the pre-selected level of significance (e.g., $\alpha=0.05$ ), then the hypothesis about the agreement of independent experts" "judgments" is not rejected.

The significance $\chi^{2}$ of the concordance coefficient is calculated as follows [59]:

$$
\chi_{\alpha, v}^{2}=W r(m-1)=\frac{12 S}{r m(m+1)-\frac{1}{m-1} \sum_{k=1}^{r} T_{k}} .
$$

If the $\chi_{\alpha, v}^{2}>\chi_{c r i t}^{2}$ the significance of concordance coefficient exists on $\alpha$ level, then the agreement of experts' opinions is satisfactory and group opinion is established. Otherwise, when $\chi_{\alpha, v}^{2}<\chi_{c r i t}^{2}$ is obtained, the respondents' opinions are not in agreement, which implies that they differ substantially and the hypothesis on the rank's correlation cannot be accepted.

If number of attributes $m$ is from 3 to $7(3 \leq m \leq 7)$, the $\chi^{2}$ distribution should be chosen.

Research started with the state-of-the-art review of similar studies and analysis of sustainability indicators proposed by the other authors as well as sustainability rating systems (i.e., BREEAM, LEED, CASBEE, etc.). Unsurprisingly, many sustainability indicators (in total 246) in the literature were found. Therefore, the main challenge was not the lack of indicators, but the selection of the most suitable indicators for assessment of the new residential projects. To solve this problem, the panel of experts, consisting of professionals and academics from the three Baltic States, was established. Profile of experts is provided in Table 2. 
Table 2. Profile of experts.

\begin{tabular}{|c|c|c|c|c|}
\hline No. & Country & Specialty & Work Experiences (Years) & Expertise in Sustainability Issues \\
\hline E1 & Lithuania & Civil engineer & 10 & $\begin{array}{l}\text { Consultant in buildings' certification according to } \\
\text { the BREEAM system }\end{array}$ \\
\hline E2 & Lithuania & $\begin{array}{l}\text { Academic (Dr., } \\
\text { Assoc. Prof.) }\end{array}$ & 11 & $\begin{array}{l}\text { Teaches subject "Sustainable development of } \\
\text { territories", took internship in the Lithuanian Real } \\
\text { Estate Developers Association }\end{array}$ \\
\hline E3 & Lithuania & Analyst & 15 & $\begin{array}{l}\text { Works in State Enterprise Centre of Registers, } \\
\text { prepares market reviews that consider sustainability } \\
\text { issues }\end{array}$ \\
\hline $\mathrm{E} 4$ & Latvia & Surveyor & 20 & Consults clients on sustainability issues \\
\hline E5 & Latvia & $\begin{array}{l}\text { Academic (Dr., } \\
\text { Assoc. Prof.) }\end{array}$ & 18 & $\begin{array}{l}\text { Teaches subject "Sustainable urban development", } \\
\text { participates in international projects }\end{array}$ \\
\hline E6 & Latvia & Architect & 10 & Designs passive houses \\
\hline E7 & Estonia & $\begin{array}{l}\text { Real estate } \\
\text { developer }\end{array}$ & 12 & Develops innovative residential projects \\
\hline E8 & Estonia & Valuator & 10 & Valuates real estate \\
\hline E9 & Estonia & $\begin{array}{l}\text { Academic (Dr., } \\
\text { Assoc. Prof.) }\end{array}$ & 32 & $\begin{array}{l}\text { Researches housing sustainability issues, participates } \\
\text { in international projects }\end{array}$ \\
\hline
\end{tabular}

Each expert was asked to select the most important indicators, assuming that indicators must be relevant to the three dimensions of sustainability, measurable, clear, and adaptable to the assessment of the new residential projects in the Baltic context. Selected indicators were discussed during online meetings, categorised and finalised. Finally, the hierarchically structured system of 53 indicators was developed (see Table 3).

Table 3. Hierarchically structured system of sustainability indicators for new residential projects.

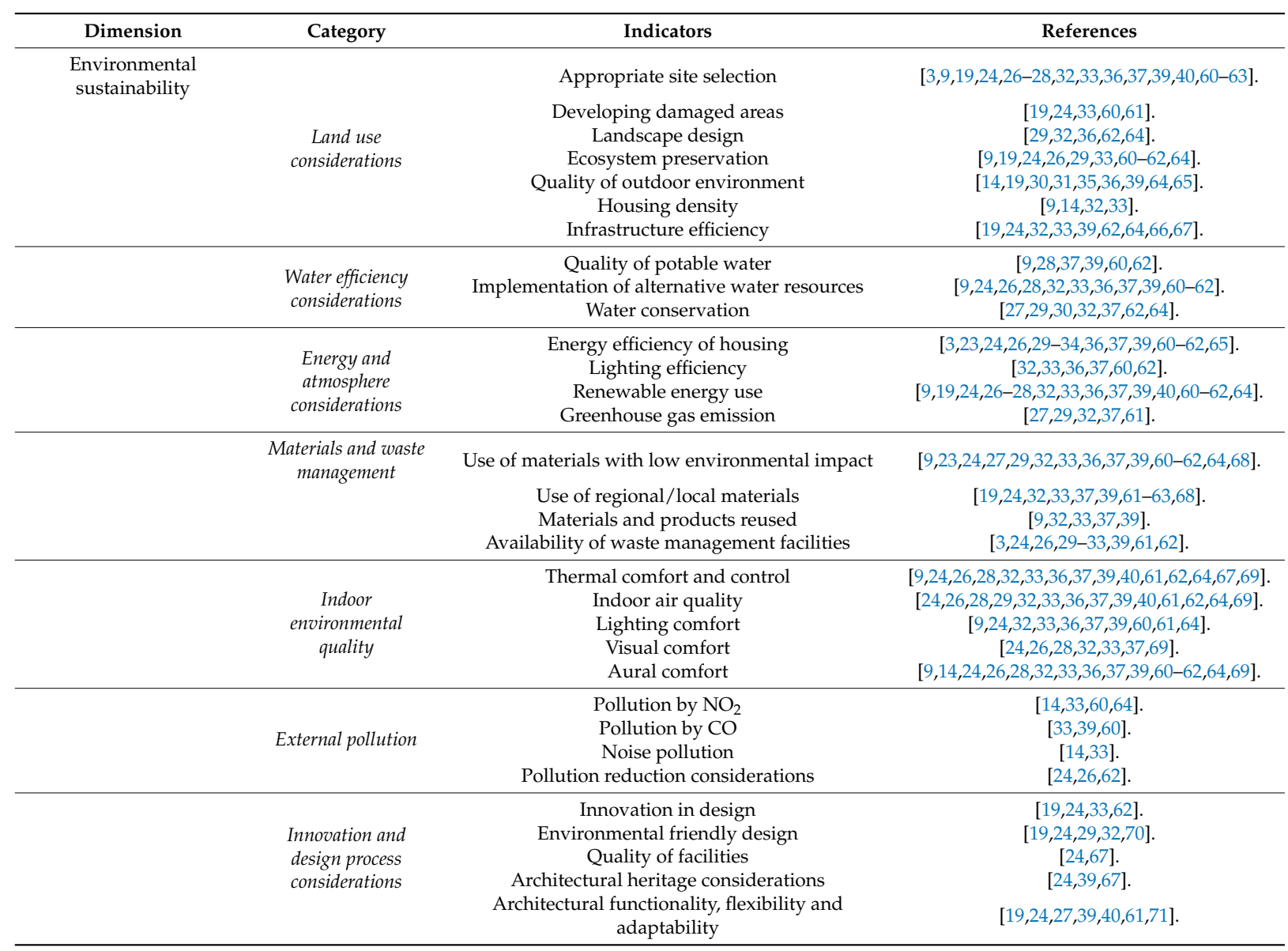


Table 3. Cont.

\begin{tabular}{|c|c|c|c|}
\hline Dimension & Category & Indicators & References \\
\hline \multirow{15}{*}{ Social sustainability } & \multirow{10}{*}{ Accessibilities } & Distance to the city centre & {$[14]$} \\
\hline & & Access to public transportation & {$[3,9,14,19,24,29-33,36-39,60,65]$. } \\
\hline & & Access to employment opportunities & {$[14,24,30,31,37,65]$} \\
\hline & & Access to educational & {$[14,30,31,65]$.} \\
\hline & & $\begin{array}{l}\text { institutions } \\
\text { Access to shops }\end{array}$ & [31.65] \\
\hline & & Access to health care services & {$[14,30,31,65]$} \\
\hline & & Access to child care & {$[14,31,65]$} \\
\hline & & Access to leisure facilities & {$[14,31,39,65]$} \\
\hline & & Access to open green public space & {$[31,39,65]$. } \\
\hline & & Car parking capacity & {$[31,65]$. } \\
\hline & \multirow{5}{*}{$\begin{array}{l}\text { Neighbourhood } \\
\text { /community } \\
\text { considerations }\end{array}$} & Safety (crime rate) & {$[14,24,29-31,35,65]$.} \\
\hline & & Neighbourhood reputation & {$[31,35,65]$} \\
\hline & & Population density & {$[14,38,39]$} \\
\hline & & Community cohesion & {$[29,30,33]$} \\
\hline & & Privacy & $\begin{array}{l}{[35,37] .} \\
{[37,60] .}\end{array}$ \\
\hline \multirow{6}{*}{ Economic sustainability } & & Costs of construction & {$[9,24,26,28,33,37,40,61]$.} \\
\hline & & Housing affordability & {$[14,27,30,31,65]$} \\
\hline & & Mortgage interest rates & {$[31,65]$} \\
\hline & & Value stability & {$[24,27,28,33]$} \\
\hline & & Added value & {$[14,19,24,30,40,63]$. } \\
\hline & & Satisfaction of demand & {$[29,35,37,40,63]$} \\
\hline
\end{tabular}

The next important step was determining significances of indicators. Experts were asked to fill pair-wise comparison matrixes. To simplify the survey and calculations, an open source BPMSG AHP Online System [72] was used. Weights and ranks, determined by each expert, and explanation of indicators are provided in Supplementary Materials (Tables S1-S4).

\section{Results and Discussion}

The main criteria for sustainability assessment of the new housing development projects in the Baltic States were divided into three hierarchical levels: Sustainability dimensions, Categories and Indicators. Since the aim of this study was to establish the most applicable assessment categories and indicators for the Baltic States, some new categories and indicators have been developed in this research (see Figure 2), and are discussed below. 


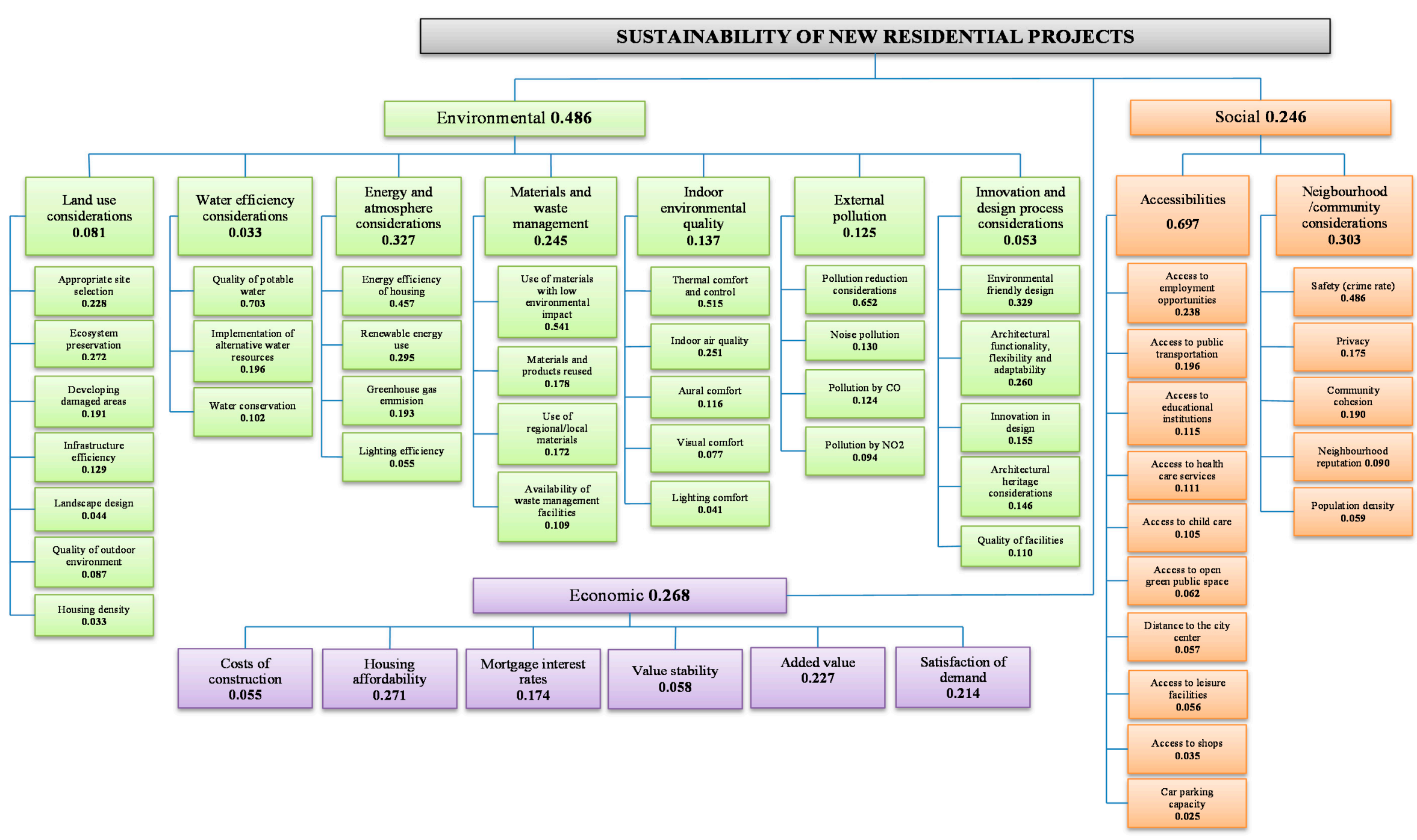

Figure 2. Hierarchical structure of sustainability indicators and their significances. 


\subsection{Environmental Sustainability Dimension}

As was previously observed, environmental dimension is mostly researched in the literature and extensively used in certification systems; therefore, it involves large amount of indicators. In this research, for this dimension, seven categories of indicators were distinguished (see Figure 3).

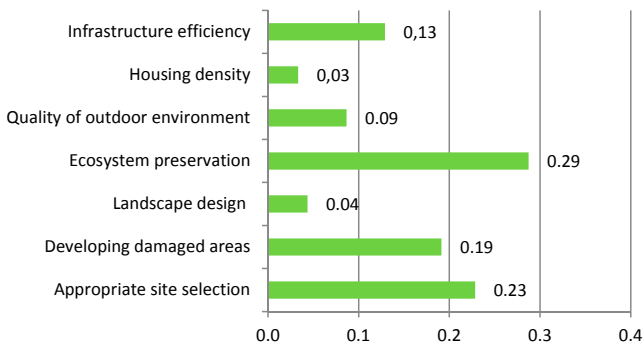

(a)

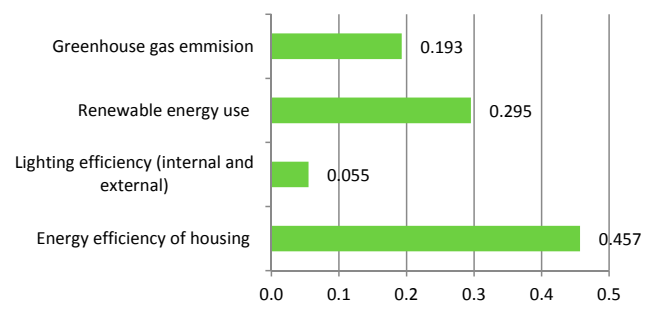

(c)

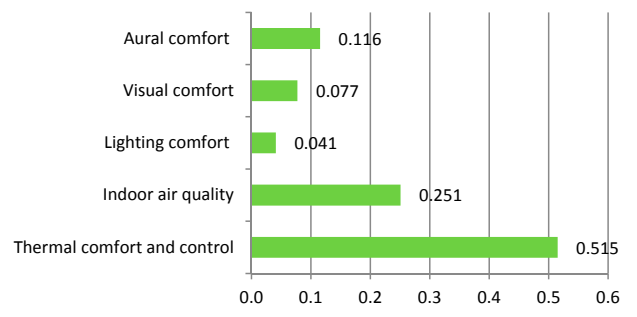

(e)

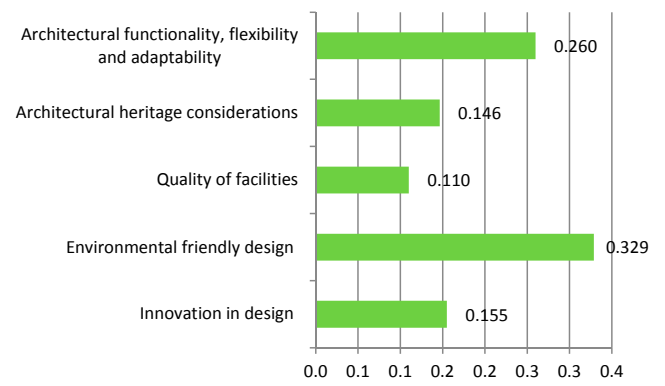

(g)

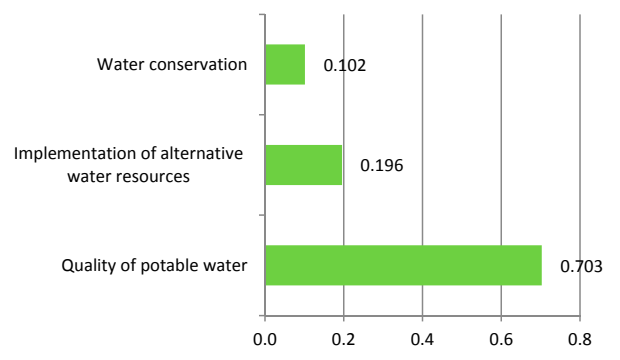

(b)

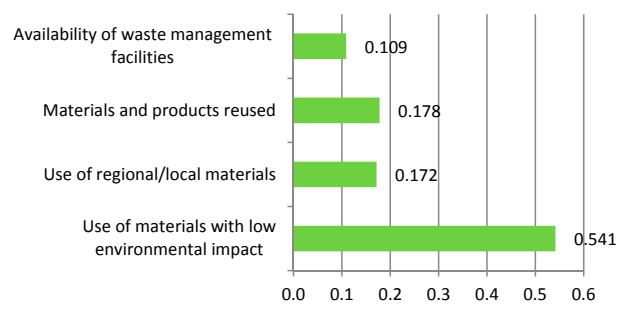

(d)

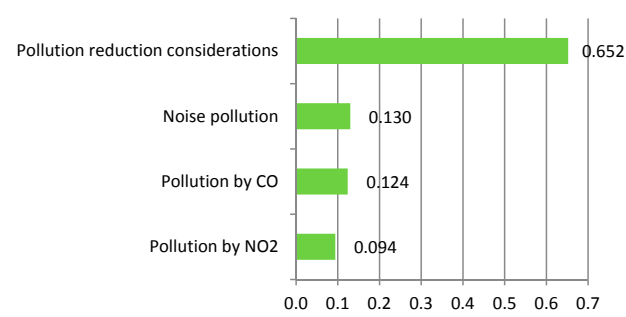

(f)

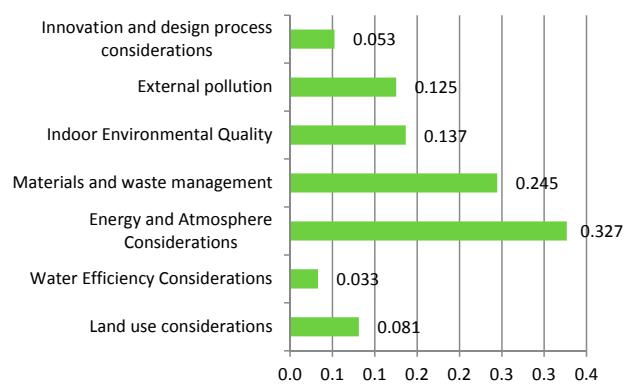

(h)

Figure 3. Rankings of environmental sustainability indicators: (a) land use considerations; (b) water efficiency considerations; (c) energy and atmosphere considerations; (d) materials and waste management; (e) indoor environmental quality; (f) external pollution; (g) innovation and design process considerations; and (h) categories of environmental indicators.

\subsubsection{Land Use Considerations}

Sustainability of the new housing projects directly depends on appropriate land use, as land is limited recourse and has impact to the other categories of sustainability. Selection of the land site is associated with the location of building itself and its infrastructure. Seven indicators (see Figure 3a), 
according to experts, encourage sustainable development and promote developing of damaged areas, ecosystem preservation, sustainable landscape and quality of outdoor environment, housing density, whilst ensuring that buildings are adequately connected to basic infrastructure. The panel of experts gave priorities to "ecosystem preservation" (0.287), "appropriate site selection" (0.228) and "infrastructure efficiency" (0.129).

These rankings correspond to the findings of other authors, e.g., research by Alyami et al. [33] revealed that site selection, transport links are among the most important sustainable land use indicators. Similarly, the study by Nilashi et al. [36] revealed that site design and transportation are the most important criteria in ratings of green buildings. Ali and Al Nsairat [26] also pointed the importance of infrastructure efficiency and land use in Jordan.

\subsubsection{Water Efficiency Considerations}

Water efficiency in this research was described by three indicators (see Figure 3b): quality of potable water and strategies (reuse of rain and grey water and water conservation) that have significant impact on reducing the overall water consumption. It is observed, however, that experts gave strong priority to the "potable water quality" (0.703). Water resources are sufficient in the Baltic States, thus water conservation and reuse are not among priorities like in hot climate zones, for instance, Saudi Arabia [33] or Jordan [26].

\subsubsection{Energy and Atmosphere Considerations}

Indeed, energy efficiency is one of the most important categories in achieving sustainable development goals. It is prioritised in sustainability rating systems as BREEAM [60], GBTool [61], LEED [62] and CASBEE [64]. In the Baltic States, like in other European countries, energy efficiency of buildings is assessed by the energy efficiency classes. In terms of energy performance, buildings are divided into the following nine classes: $\mathrm{A}++, \mathrm{A}+, \mathrm{A}, \mathrm{B}, \mathrm{C}, \mathrm{D}, \mathrm{E}, \mathrm{F}$ and $\mathrm{G}$. The highest class A++ indicates that the building consumes almost no energy, whereas classes $\mathrm{A}+, \mathrm{A}$ and $\mathrm{B}$ signify that buildings consume little energy. Energy efficiency class is determined according to properties of the building, e.g., building envelope performance, efficiency of HVAC system, windows, doors, etc. Moreover, renewable energy use and lighting efficiency is encouraged. Energy efficiency of the buildings directly contributes to reduction of greenhouse gas emission.

The panel of experts gave priorities to "energy efficiency of housing" (0.457), "renewable energy use" (0.295) and "greenhouse gas emission" (0.295). "Lighting efficiency" was assessed as less important indicator (0.055) (see Figure 3c).

Importance of building envelope performance, efficiency of HVAC system, reduction of electricity use was also emphasised in studies of Ali and Al Nsairat [26] and Alyami et al. [33]. Similarly, the study by Nilashi et al. [37] revealed that renewable energy and building envelope performance are the most important criteria in ratings of green buildings.

\subsubsection{Materials and Waste Management}

To enhance energy efficient design of the buildings, selection of appropriate materials is vitally important. According to Shen et al. [63], "the reduced use of and therefore depletion of both limited raw materials and long-cycle renewable materials by substituting them with instantly renewable materials is crucial in achieving sustainability of buildings".

Survey of experts revealed that the choice of materials with low environmental impact (0.541), reuse of materials and products in new construction projects (0.178) are the most important considerations in the Baltic States (see Figure 3d). The findings are in line with the study of Alyami et al. [33], where Delphi survey panel distinguished the choice of "materials with low environmental impact" along with "building fabric components" as the most important considerations. Similarly, the study by Nilashi et al. [37] revealed that environmental impact of materials, resource reuse and use of renewable materials are the most important criteria in ratings of green buildings. 
The panel of experts also considered the "use of regional/local materials" (0.172) as important indicator. According to Shen et al. [63] and Pearce et al. [68], implementation of regional materials contributes to the regional economy and reduces environmental effects from transportation. This indicator also was assessed as very important in study by Ali and Al Nsairat [26].

"Availability of waste management facilities" in this study was ranked as a less important indicator, as, in the Baltic States, all new housing projects must be equipped with appropriate waste management facilities, including recycling facilities.

\subsubsection{Indoor Environmental Quality}

Category of the "indoor environmental quality" included five indicators (see Figure 3e): thermal, aural, visual, lighting comfort and indoor air quality. The panel of experts gave priorities to "thermal comfort and control" (0.515), "indoor air quality" (0.251) and "aural comfort" (acoustics and noise protection) (0.116).

In the Baltic States, due to cold winters, appropriate heating strategies are among the most important considerations. Indoor air quality directly influences health of the occupants. Importance of thermal comfort and control was also emphasised in international studies of Mateus and Bragança [9], Abdul-Rahman et al. [24], Alyami et al. [33]; Yu et al. [36]; Nilashi et al. [37], Ceron-Palma et al. [67]; and Lai et al. [69], as well as certification systems such as GBTool [61], LEED [62], and CASBEE [64].

To ensure high indoor air quality for occupants, controllability of systems (thermal, ventilation and lighting systems) should be implemented. Similarly, as in this research, the study by Nilashi et al. [37] revealed indoor air performance among the most important criteria in ratings of green buildings.

Aural comfort, which focuses on ensuring that building walls and floor systems are designed with sufficient sound absorption capability to sustain suitable acoustical quality for occupants and neighbours [69], is assumed to be important indicator as many of the occupants of new residential apartments comply for insufficient acoustical insulation and suffer from noise, as it was noted by experts from Lithuania.

The panel of experts assigned lower significances to "visual comfort" (0.077) and "lighting comfort" (0.041) as these indicators mostly depend on the actions of residents and usually new residential apartments in the Baltic States are sold with partial finishing.

\subsubsection{External Pollution}

This category included four indicators (see Figure 3f). Pollution indicators (pollution by $\mathrm{NO}_{2}$, $\mathrm{CO}$ and noise pollution) were assessed with similar importance; however, these indicators should be investigated in each project. Indeed, experts gave priority to pollution reduction considerations $(0.652)$ as manageable strategies, which "relate to efficient land use and actions taken to prevent land-based pollution" [24].

\subsubsection{Innovation and Design Process Considerations}

Five indicators were assessed by experts for innovation and design process considerations (see Figure 3g): "innovation in design"; "environmental friendly design"; "quality of facilities"; "architectural heritage considerations"; and "architectural functionality, flexibility and adaptability".

Innovation in design offers design teams and project participants the opportunity to be awarded for performance above minimum requirements [70]. Moreover, it leads to environmental efficient design. "Eco-innovation does not necessarily mean expensive solutions, but rather ones that are technically robust, socially responsible, and financially viable" [4]; these also include provision of high quality facilities.

Architectural heritage considerations focus on prevention of negative impact of project development on any kind of cultural heritage [24]. Moreover, buildings should provide proper functionality, flexibility and adaptability to residents' needs [24,71]. 
In this research, "environmental friendly design" (0.329), "architectural functionality, flexibility and adaptability" (0.260) and "innovation in design" (0.155) were recognised as the most important indicators. These indicators are promoted by Lithuanian Real Estate Developers Association [19], and are also highlighted in studies by Abdul-Rahman et al. [24], Alwaer and Clements-Croome [27], and Bakar et al. [29].

The panel of experts also ranked the categories of environmental sustainability (see Figure $3 \mathrm{~h}$ ). The judgement is that "energy and atmosphere considerations" (0.327) and "materials and waste management" (0.245) are the top priorities of the new residential projects in the Baltic States. "Indoor environmental quality" (0.137) and "external pollution" (0.125) were ranked as less significant, but still important indicators. These findings correspond to rankings of the mostly used sustainability rating systems, i.e., BREEAM [60], LEED [62] and CASBEE [64]. Energy efficiency and use of environmental friendly materials was also distinguished as the most important in the Portuguese context [9] and sustainable social housing projects in the UK [35].

Lower significances were assigned to "land use considerations" (0.081), "innovation and design process considerations" (0.053) and "water efficiency considerations" (0.033). Similar findings were achieved in raking of sustainability indicators in Portugal [9] and the Slovak Republic [39].

In the Baltic States, land use for the new construction is restricted by local legal acts and land use regulations in general follow the principles of sustainable development. Innovation and design process considerations are related to other (according to expert judgments), more significant categories, i.e., energy and material use considerations. The quality of water is rather high in the living districts of the Baltic States; therefore indicator was estimated as being least significant. "Water efficiency" and "waste management cost" were also found as least important criteria in the study by Ali and Al Nsairat [26].

\subsection{Social Sustainability Dimension}

Sustainable housing is characterized as being available, good quality, economical, ecological, comfortable and cosy. For communities to be sustainable, they must provide hospitals, schools, shops, good public transport, open public spaces and a clean and safe environment [30]. Therefore, social sustainability dimension was divided into two categories: "accessibilities" and "neighbourhood /community considerations" (see Figure 4).

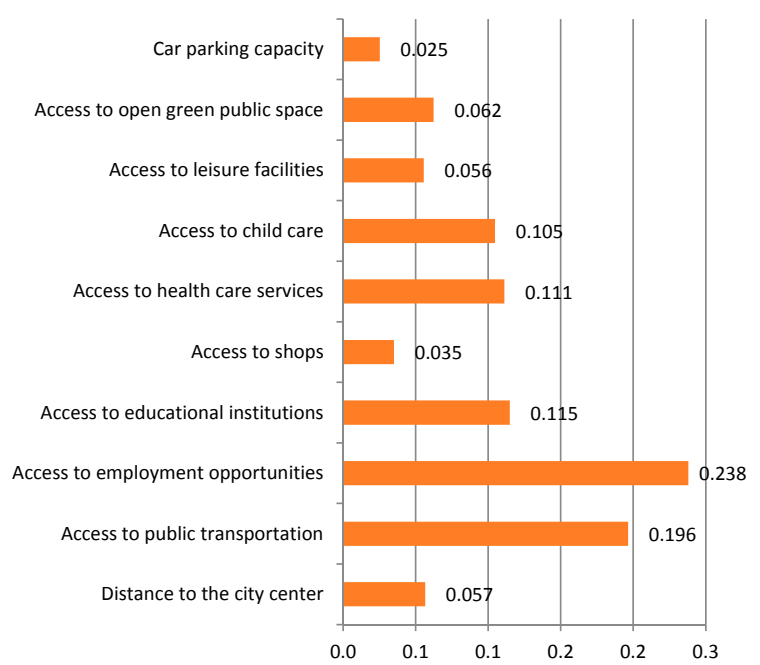

(a)

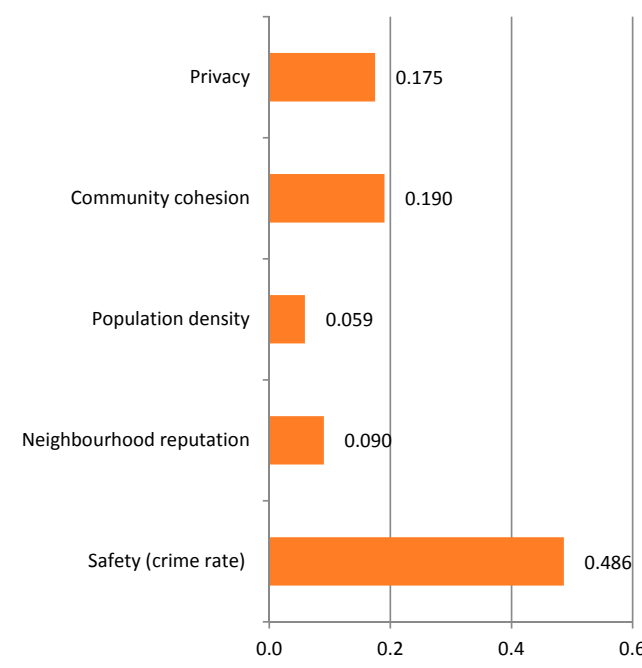

(b)

Figure 4. Cont. 


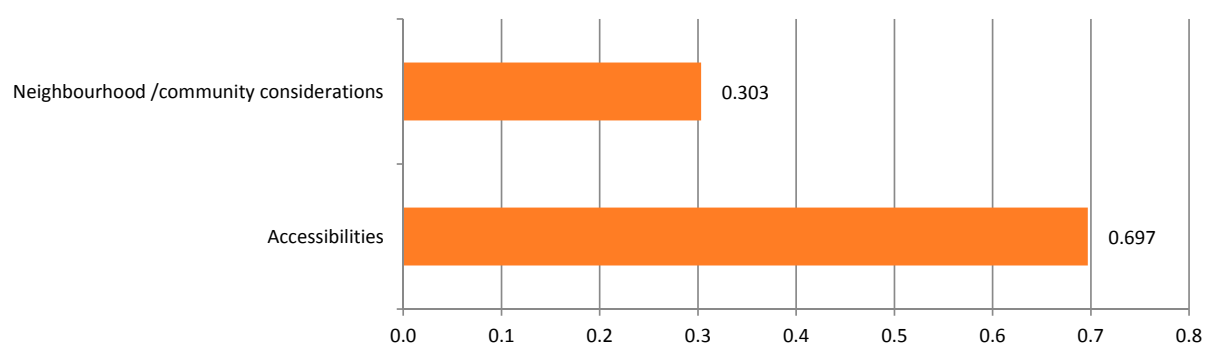

(c)

Figure 4. Rankings of social sustainability indicators: (a) acessibilities; (b) neighbourhood/community considerations; and (c) categories of social indicators.

\subsubsection{Accessibilities}

In the category of "accessibilities", ten indicators were distinguished (see Figure 4a), including access to public transportation, urban amenities and employment opportunities. The top priority indicators, according to estimates of experts are "access to employment opportunities" (0.238) and "access to public transportation" (0.196). Similar findings were observed in the study by Mulliner et al. [31], where "access to employment opportunities" and "public transport services" were top priority criteria among other accessibility indicators in assessment of sustainable housing affordability in the UK. Access to services was also in priority of the sustainability assessment of social housing regeneration projects in the UK [35].

Indeed, according to experts, availability of public transportation directly influences access to the most important public amenities: education institutions (0.115), health care services $(0.111)$ and child care institutions (0.105). Less important indicators are "distance to the city centre" $(0.057)$, "access to leisure facilities" (0.056), "access to open green public space" (0.062) and "car parking capacity" (0.025).

In a survey by Turcu [30], over $60 \%$ of residents rated access to public transport, health services, jobs, green open spaces as "very important" (in the UK). Similarly, the study by Nilashi et al. [37] revealed that accessibility to urban amenities and public transportation are the most important criteria in ratings of green buildings, moreover, "local employment opportunities" were evaluated as one of the most important externalities in social dimension. The same results were obtained in ranking of sustainability indicators in Portugal [9].

\subsubsection{Neighbourhood/Community Considerations}

In this research, "Neighbourhood/community considerations" included five indicators: "safety", "neighbourhood reputation", "community cohesion", "population density in living area" and "privacy" (see Figure $4 b$ ).

Panel of experts assigned highest significance to "safety (crime rate)" indicator (0.486). This finding corresponds to findings of many studies. For instance, according to Ceccato and Lukyte [73], "a sustainable community shall be a place free from the fear of crime, where a feeling of security underpins a wider sense of place attachment and place attractiveness". Research by Zavadskas et al. [14] indicated safety as the most important criterion in social dimension for assessment sustainability of Vilnius districts. In a survey by Turcu [30] (the UK), over $80 \%$ of residents rated safety as "very important". Crime and cohesion indicators were also emphasised in the sustainability assessment of social housing regeneration projects in the UK [41].

In the second place, according to judgment of experts, are indicators "community cohesion" (0.190) and "privacy" (0.175), although "privacy" was ranked as the most important criterion of occupants' satisfaction in the study by Nilashi et al. [37].

Indicators that were considered as less important are "neighbourhood reputation" (0.09) and "population density" (0.059). These indicators are directly related to the above mentioned indicators. 
Of two categories of social sustainability, "accessibilities" (0.697) were considered as more important than "neighbourhood considerations" (0.303) (see Figure 4c).

\subsection{Economic Sustainability Dimension}

As was previously noted, the developed hierarchical system of indicators for sustainability assessment is limited to new residential projects in the Baltic States, therefore maintenance and operational costs as well as life cycle assessments, considered by many authors, are not estimated. The panel of experts has chosen six economic indicators pertinent to new housing projects (see Figure 5).

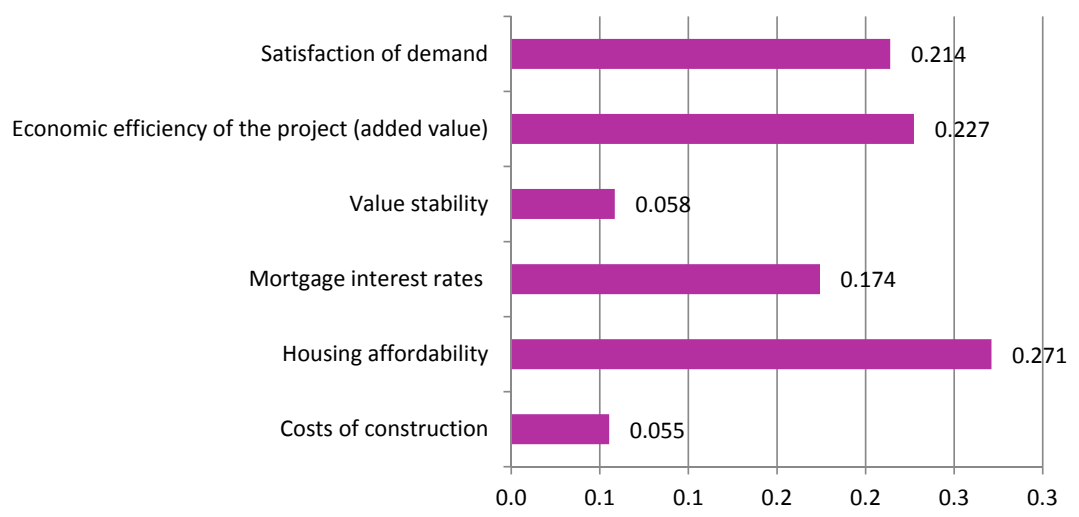

Figure 5. Ranking of economic sustainability indicators.

"Housing affordability" (price in relation to income) was ranked as the most significant (0.271) followed by "added value of the project" (0.227), "satisfaction of housing demand" (0.214) and "mortgage interest rates" (0.174). "Value stability" (0.058) and "costs of construction" (0.055) were considered less significant.

According to Mulliner et al. [31], most importantly, "sustainable communities must provide decent homes at prices people can afford". A survey of experts done by Zavadskas et al. [14] revealed that housing price is the most important criterion in assessment of sustainable built environment in Vilnius districts. In a survey by Turcu [30] (the UK), over 60\% of residents rated housing affordability as "very important". The same findings were achieved in the study by Mulliner et al. [31] where housing affordability was ranked as the most important criterion in assessment of sustainable housing affordability in the UK districts.

\subsection{Ranking of Sustainability Dimensions}

Finally, experts were asked to rank three major sustainability dimensions (see Figure 6). These three elements are included in most studies which focus on sustainable development in the construction industry.

According to experts, in achieving sustainability of the new residential projects, environmental sustainability (0.486) is considered as more significant than the other two dimensions. Not surprisingly, higher rank is also assigned to economic dimension (0.268) as economic issues are among priorities in transitional countries as the Baltic States are. Notwithstanding, social dimension was also considered important (0.246). 


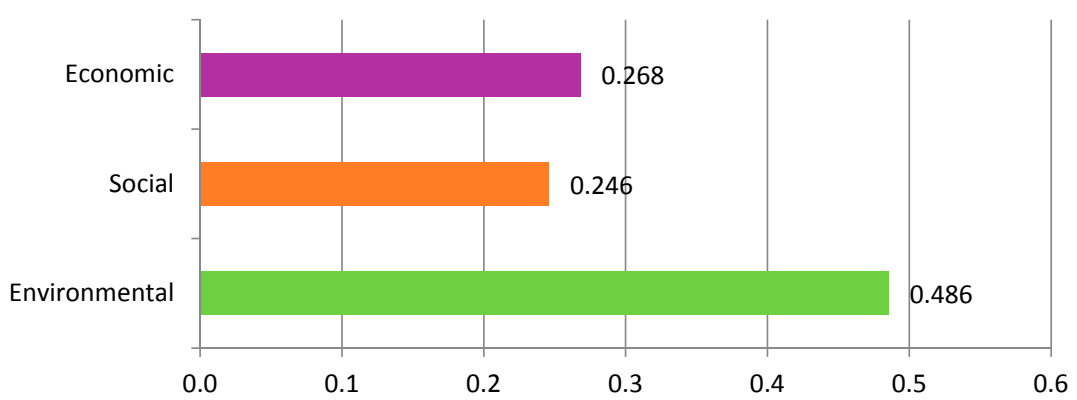

Figure 6. Ranking of sustainability dimensions.

Many researchers found that environmental sustainability in similar studies is in the first place (e.g., [24,37]). However, economic and social dimensions are ranked differently. In studies by Nilashi et al. [37] and Abdul-Rahman et al. [24], social dimension was ranked higher than economic. On the other hand, Higham et al. [41] found that economic criteria are perceived as more important than the social or environmental factors in housing projects' feasibility stage investment decisions. Actually, as it was noted by Heravi et al. [2] and Shen et al. [63] that the social dimension of sustainability is to some extent challenging. Although there is an agreement on indicators such as cultural effects and public related issues, as social ones, some of them such as employment, safety, and indoor air quality are sometimes considered economic and environmental indicators [2].

\subsection{Recommendations}

This research suggests some recommendations that might be useful to government authorities and real estate developers as to how to enhance the performance of new housing development projects according to the principles of sustainability:

1. Research revealed that sustainable new housing development projects should encompass three main sustainability dimensions: environmental, economic and social. This triangular sustainability should be incorporated in local strategies and assessed according to substantial indicators. Developing such assessment framework should be based on scientific research and practical knowledge. Experts, designers, developers and other stakeholders should be introduced as key participants in this process. As proposed by Scolobig and Lilliestam [74], "stakeholders' perspectives can be included in the shape of qualitative, quantitative, or mixed data, and often a translation of qualitative views into alternatives, technical options, models, or scenarios-including quantification efforts adds difficulty and complexity to the process, but can also enrich the final outcome".

2. Energy and atmosphere considerations, materials and waste management are among the top priorities of the new residential projects in the Baltic States. Therefore, developers are encouraged to build new energy efficient residential buildings from environmental friendly, reused and recycled materials. Moreover, from the economic point of view, these projects should be affordable and from the social perspective-infrastructure efficient in respect to public transportation and access to the most important public amenities (schools, kinder gardens, healthcare institutions, etc.).

3. To promote sustainable new residential projects, the national contests could be organised in Latvia and Estonia. Good practice example in this case is initiative of the Lithuanian Real Estate Developers Association.

4. As the findings of research were in line with the findings of the other authors, it is suggested that Baltic States can learn sustainability principles from the other countries' work, ideas, frameworks, and best practices; however, new sustainable residential projects should suit the local context, depending on the culture, legislation, policy, stakeholders, practices and institutions. 


\section{Conclusions}

This publication aimed to propose an integrated, hierarchically structured system of sustainability indicators to be used for assessment of the new housing development projects in the Baltic States, as no existing comprehensive framework including all three aspects of sustainability was found in practice and the literature.

The main criteria for sustainability assessment of the new housing development projects in the Baltic States were divided into three hierarchical levels: sustainability dimensions, categories and Iindicators. Since the aim of this study was to establish the most applicable assessment categories and indicators for the Baltic States, some new categories and indicators were developed in the research. Each category consisted of several indicators, within which 53 indicators were addressed. Selection of categories and indicators depended mainly on the ranking of the importance and relevance to the local situation.

Rankings of the sustainability indicators by the experts revealed that, in dimension of environmental sustainability, "energy and atmosphere considerations", "materials and waste management" are the top priorities of the new residential projects in the Baltic States. "Indoor environmental quality" and "external pollution" were ranked as less significant, but still important indicators.

In the social dimension, "accessibilities" were considered as more important than "neighbourhood considerations". In the category of "accessibilities", the top priority indicators, according to estimates of experts, were "access to employment opportunities" and "access to public transportation".

In the economic dimension, "housing affordability" indicator was ranked as the most significant followed by "added value of the project", "satisfaction of housing demand" and "mortgage interest rates".

According to experts, in achieving sustainability of the new residential projects, environmental sustainability is considered as more significant than the other two dimensions. Higher rank was assigned to economic dimension. Notwithstanding, social dimension was also considered as important.

In this research, some limitations exist, which need to be solved in future studies. First, there were a small number of experts in fulfilling the survey. Different groups of experts could participate in refining of the hierarchical system of criteria and determining the significances of indicators. Second, the proposed system of sustainability indicators is limited to assessment of the new residential development projects in the Baltic States. For assessment of the other types of projects in context of the other countries, individual systems should be developed. Third, the developed hierarchical system of indicators should be tested in assessment of the real development projects; it is being solved in the authors' on-going research "Sustainability assessment of the new residential projects in the Baltic States". In this research, nine new residential projects in Lithuania, Latvia and Estonia will be assessed according to the hierarchical system of indicators as proposed in Figure 2. Significances of indicators, categories and dimensions will be used for multiple criteria assessment of the projects by the SAW method. Multiple criteria assessments will be performed according to indicators in each category and in each dimension. Finally, integrated assessment of the buildings' sustainability and ranks will be obtained. Authors believe that this research will provide solid information about sustainability of the new residential projects in the Baltic States.

Supplementary Materials: The following are available online at www.mdpi.com/2079-9276/6/4/55/s1, Table S1: Determining significances of indicators, Table S2: Determining significances of categories, Table S3: Determining significances of dimensions; Table S4: Explanation of indicators.

Acknowledgments: This work was partly supported by institutional research funding of the Estonian Ministry of Education and Research IUT1-15 "Nearly-zero energy solutions and their implementation on deep renovation of buildings".

Author Contributions: Laura Tupenaite and Jurga Naimaviciene researched, summarised literature and designed the methodology; Irene Lill, Ineta Geipele and Jurga Naimaviciene performed the survey of experts in the Baltic States; Laura Tupenaite performed calculations; and all of the authors contributed to discussion of results, conclusions and writing the paper. 
Conflicts of Interest: The authors declare no conflict of interest.

\section{References}

1. World Commission on Environment and Development. Our Common Future; Oxford University Press: New York, NY, USA, 1987; Available online: http:/ /www.un-documents.net/our-common-future.pdf (accessed on 7 May 2017).

2. Heravi, G.; Fathi, M.; Faeghi, S. Evaluation of sustainability indicators of industrial buildings focused on petrochemical projects. J. Clean. Prod. 2015, 109, 92-107. [CrossRef]

3. Holmstedt, L.; Brandt, N.; Robèrt, K.-H. Can Stockholm Royal Seaport be part of the puzzle towards global sustainability?-From local to global sustainability using the same set of criteria. J. Clean. Prod. 2017, 140, 72-80. [CrossRef]

4. Zhang, X.; Shen, L.; Wu, Y. Green strategy for gaining competitive advantage in housing development: A China study. J. Clean. Prod. 2011, 19, 157-167. [CrossRef]

5. Hwang, B.G.; Tan, J.S. Green building project management: obstacles and solutions for sustainable development. Sustain. Dev. 2012, 20, 335-349. [CrossRef]

6. Arman, M.; Zuo, J.; Wilson, L.; Zillante, G.; Pullen, S. Challenges of responding to sustainability with implications for affordable housing. Ecol. Econ. 2009, 68, 3034-3041. [CrossRef]

7. Maliene, V.; Malys, N. High-quality housing-a key issue in delivering sustainable communities. Build. Environ. 2009, 44, 426-430. [CrossRef]

8. European Commission (EC). Energy Roadmap 2050; European Commission: Brussels, Belgium, 2011; Available online: https: / ec.europa.eu/energy/sites/ener/files/documents/2012_energy_roadmap_2050_en_0.pdf (accessed on 10 May 2017).

9. Mateus, R.; Braganca, L. Sustainability assessment and rating of buildings: Developing the methodology SBToolPT-H. Build. Environ. 2011, 46, 1962-1971. [CrossRef]

10. Egilmez, G.; Gumus, S.; Kucukvar, M. Environmental sustainability benchmarking of the U.S. and Canada metropoles: An expert judgment-based multi-criteria decision making approach. Cities 2015, 42, 31-41. [CrossRef]

11. Capolongo, S.; Buffoli, M.; Oppio, A.; Petronio, M. Sustainability and hygiene of building: Future perspectives. Epidemiol. Prev. 2014, 38, 46-50. [PubMed]

12. Zhang, X.; Wu, Y.; Shen, L.; Skitmore, M. A prototype system dynamic model for assessing the sustainability of construction projects. Int. J. Proj. Manag. 2014, 32, 66-76. [CrossRef]

13. Viteikiene, M.; Zavadskas, E.K. Evaluating the sustainability of Vilnius city residential areas. J. Civ. Eng. Manag. 2007, 13, 149-155.

14. Zavadskas, E.K.; Cavallaro, F.; Podvezko, V.; Ubarte, I.; Kaklauskas, A. MCDM assessment of a healthy and safe built environment according to sustainable development principles: A practical neighborhood approach in Vilnius. Sustainability 2017, 9, 702. [CrossRef]

15. Brizga, J. How well sustainable development is integrated into environmental policies? Case study: Latvia. Saf. Technol. Environ. 2012, 2, 24-34.

16. Zilans, A.; Abolina, K. A methodology for assessing urban sustainability: Aalborg commitments baseline review for Riga, Latvia. Environ. Dev. Sustain. 2009, 11, 85-114. [CrossRef]

17. Geipele, I.; Kauškale, L.; Lepkova, N.; Liias, R. Interaction of socio-economic factors and real estate market in the context of sustainable urban development. In Proceedings of the 9th International Conference "Environmental Engineering", Vilnius, Lithuania, 22-23 May 2014; pp. 1-8.

18. Nuuter, T.; Lill, I.; Tupenaite, L. Comparison of housing market sustainability in European countries based on multiple criteria assessment. Land Use Policy 2015, 42, 642-651. [CrossRef]

19. Lithuanian Real Estate Developers Association (LNTPA). Available online: http://lntpa.lt/darnios-pletrosakademija/konkursai-uz-darnia-pletra-ir-darni-aplinka/ (accessed on 10 July 2017).

20. Latvian Sustainable Building Council (LSBC). Available online: http://www.ibp.lv/en (accessed on 10 July 2017).

21. Estonian Green Building Council (Eesti GBC). Available online: http://www.gbc.ee/gbc_eng.html (accessed on 10 July 2017). 
22. Agol, D.; Latawiec, A.E.; Strassburg, B.B.N. Evaluating impacts of development and conservation projects using sustainability indicators: Opportunities and challenges. Environ. Impact Assess. Rev. 2014, 48, 1-9. [CrossRef]

23. Wallbaum, H.; Ostermeyer, Y.; Salzer, C.; Zea Escamilla, E. Indicator based sustainability assessment tool for affordable housing construction technologies. Ecol. Indic. 2012, 18, 353-364. [CrossRef]

24. Abdul-Rahman, H.; Wang, C.; Ebrahimi, M. Integrating and ranking sustainability criteria for housing. Proc. Inst. Civ. Eng. Eng. Sustain. 2016, 169, 3-30. [CrossRef]

25. Berardi, U. Clarifying the new interpretations of the concept of sustainable building. Sustain. Cities Soc. 2013, 8, 72-78. [CrossRef]

26. Ali, H.H.; Al Nsairat, S.F. Developing a green building assessment tool for developing countries e case of Jordan. J. Build. Environ. 2009, 44, 1053-1064. [CrossRef]

27. Alwaer, H.; Clements-Croome, D.J. Key performance indicators (KPIs) and priority setting in using the multi-attribute approach for assessing sustainable intelligent buildings. J. Build. Environ. 2010, 45, 799-807. [CrossRef]

28. Bragança, L.; Mateus, R.; Koukkari, H. Building sustainability assessment. Sustainability 2010, 2, $2010-2023$. [CrossRef]

29. Bakar, A.H.A.; Cheen, K.S. Sustainable housing practices in Malaysian housing development: Towards establishing sustainability index. IJTech 2011, 1, 84-93.

30. Turcu, C. Re-thinking sustainability indicators: Local perspectives of urban sustainability. J. Environ. Plan. Manag. 2013, 56, 695-719. [CrossRef]

31. Mulliner, E.; Smallbone, K.; Maliene, V. An assessment of sustainable housing affordability using a multiple criteria decision making method. Omega 2013, 41, 270-279. [CrossRef]

32. Chandratilake, S.R.; Dias, W.P.S. Sustainability rating systems for buildings: comparisons and correlations. Energy 2013, 59, 22-28. [CrossRef]

33. Alyami, S.H.; Rezgui, Y.; Kwan, A. Developing sustainable building assessment scheme for Saudi Arabia: Delphi consultation approach. Renew. Sustain. Energy Rev. 2013, 27, 43-54. [CrossRef]

34. Mardani, A.; Zavadskas, E.K.; Streimikiene, D.; Jusoh, A.; Nor, K.M.D.; Khoshnoudi, M. Using fuzzy multiple criteria decision making approaches for evaluating energy saving technologies and solutions in five star hotels: A new hierarchical framework. Energy 2016, 117, 131-148. [CrossRef]

35. Higham, A.; Stephenson, P. Identifying project success criteria for UK social housing asset management schemes. In Proceedings of the 30th Annual ARCOM Conference, Association of Researchers in Construction Management, Portsmouth, UK, 1-3 September 2014; pp. 33-42.

36. Yu, W.; Li, B.; Yang, X.; Wang, Q. A development of a rating method and weighting system for green store buildings in China. Renew. Energy 2015, 73, 123-129. [CrossRef]

37. Nilashi, M.; Zakaria, R.; Ibrahim, O.; Majid, M.Z.A.; Zin, R.M.; Chugtai, M.W.; Abidin, N.I.Z.; Sahamir, S.R.; Yakubu, D.A. A knowledge-based expert system for assessing the performance level of green buildings. Knowl.-Based Syst. 2015, 86, 194-209. [CrossRef]

38. Preval, N.; Randal, E.; Chapman, R.; Moores, J.; Howden-Chapman, P. Streamlining urban housing development: Are there environmental sustainability impacts? Cities 2016, 55, 101-112. [CrossRef]

39. Burdova, E.K.; Vilcekova, S. Sustainable building assessment tool in Slovakia. Energy Procedia 2015, 78, 1829-1834. [CrossRef]

40. Kang, H.; Lee, Y.; Kim, S. Sustainable building assessment tool for project decision makers and its development process. Environ. Impact Assess. Rev. 2016, 58, 34-47. [CrossRef]

41. Higham, A.P.; Fortune, C.; Boothman, J.C. Sustainability and investment appraisal for housing regeneration projects. Struct. Surv. 2016, 34, 150-167. [CrossRef]

42. Saaty, T.L. The Analytic Hierarchy Process: Planning, Priority Setting, Resource Allocation; McGraw-Hill: New York, NY, USA, 1980.

43. Gan, X.; Fernandez, I.C.; Guo, J.; Wilson, M.; Zhao, Y.; Zhou, B.; Wu, J. When to use what: Methods for weighting and aggregating sustainability indicators. Ecol. Indic. 2017, 81, 491-502. [CrossRef]

44. Si, J.; Marjanovic-Halburd, L.; Nasiri, F.; Bell, S. Assessment of building-integrated green technologies: A review and case study on applications of Multi-Criteria Decision Making (MCDM) method. Sustain. Cities Soc. 2016, 27, 106-115. [CrossRef] 
45. Işik, Z.; Aladağ, H. A fuzzy AHP model to assess sustainable performance of the construction industry from urban regeneration perspective. J. Civ. Eng. Manag. 2017, 23, 499-509. [CrossRef]

46. Yan, M.-R.; Pong, C.-S.; Lo, W. Utility-based multicriteria model for evaluating BOT projects. Technol. Econ. Dev. Eco. 2011, 17, 207-218. [CrossRef]

47. Turskis, Z.; Morkunaite, Z.; Kutut, V. A hybrid multiple criteria evaluation method of ranking of cultural heritage structures for renovation projects. Int. J. Strateg. PROP M 2017, 21, 318-329. [CrossRef]

48. Kaya, I.; Kahraman, C. A comparison of fuzzy multicriteria decision making methods for intelligent building assessment. J. Civ. Eng. Manag. 2014, 20, 59-69. [CrossRef]

49. Gudienè, N.; Banaitis, A.; Podvezko, V.; Banaitienè, N. Identification and evaluation of the critical success factors for construction projects in Lithuania: AHP approach. J. Civ. Eng. Manag. 2014, 20, 350-359. [CrossRef]

50. Fouladgar, M.M.; Yazdani-Chamzini, A.; Lashgari, A.; Zavadskas, E.K.; Turskis, Z. Maintenance strategy selection using AHP and COPRAS under fuzzy environment. Int. J. Strateg. PROP M 2012, 16, 85-104. [CrossRef]

51. Khalil, N.; Kamaruzzaman, S.N.; Baharum, M.R. Ranking the indicators of building performance and the users' risk via Analytical Hierarchy Process (AHP): Case of Malaysia. Ecol. Indic. 2016, 71, 567-576. [CrossRef]

52. Sindhu, S.; Nehra, V.; Luthra, S. Solar energy deployment for sustainable future of India: Hybrid SWOC-AHP analysis. Renew. Sustain. Energy Rev. 2017, 72, 1138-1151. [CrossRef]

53. Banani, R.; Vahdati, M.M.; Shahrestani, M.; Clements-Croome, D. The development of building assessment criteria framework for sustainable non-residential buildings in Saudi Arabia. Sustain. Cities Soc. 2016, 26, 289-305. [CrossRef]

54. Rodriguez-Trejo, S.; Ahmad, A.M.; Hafeez, M.A.; Dawood, H.; Vukovic, V.; Kassem, M.; Naji, K.K.; Dawood, N. Hierarchy based information requirements for sustainable operations of buildings in Qatar. Sustain. Cities Soc. 2017, 32, 435-448. [CrossRef]

55. Moussaoui, F.; Cherrared, M.; Kacimi, M.A.; Belarbi, R. Genetic Algorithm to optimize consistency ratio in AHP method for energy performance assessment of residential buildingsAlgerian case study. Sustain. Cities Soc. 2017. [CrossRef]

56. Capolongo, S.; Bottero, M.C.; Buffoli, M.; Lettieri, E. (Eds.) Improving Sustainability during Hospital Design and Operation: A Multidisciplinary Evaluation Tool; Springer: Cham, Switzerland, 2015. [CrossRef]

57. Cegan, J.C.; Filion, A.M.; Keisler, J.M.; Linkov, I. Trends and applications of multi-criteria decision analysis in environmental sciences: Literature review. Environ. Syst. Decis. 2017, 37, 123-133. [CrossRef]

58. Mardani, A.; Jusoh, A.; Zavadskas, E.K.; Cavallaro, F.; Khalifah, Z. Sustainable and renewable energy: An overview of the application of multiple criteria decision making techniques and approaches. Sustainability 2015, 7, 13947-13984. [CrossRef]

59. Kendall, M.G. Rank Correlation Methods, 4th ed.; Griffin: London, UK, 1970.

60. BREEAM. Available online: http:/ / www.breeam.com/ (accessed on 15 May 2017).

61. GBTool. Available online: http://iisbe.org/gbc2k/gbtool/gbtool-main.htm (accessed on 15 May 2017).

62. LEED. Available online: https://www.usgbc.org/leed (accessed on 15 May 2017).

63. Shen, L.Y.; Tam, V.W.Y.; Tam, L.; Ji, Y. Project feasibility study: The key to successful implementation of sustainable and socially responsible construction management practice. J. Clean. Prod. 2010, 18, 254-259. [CrossRef]

64. CASBEE. Available online: http://www.ibec.or.jp/CASBEE/english/ (accessed on 15 May 2017).

65. Mulliner, E.; Malys, N.; Maliene, V. Comparative analysis of MCDM methods for the assessment of sustainable housing affordability. Omega 2016, 59, 146-156. [CrossRef]

66. Newell, P.J.; Seymour, M.; Yee, T.; Renteria, J.; Longcore, T.; Wolch, R.J.; Shishkovsky, A. Green Alley Programs: Planning for a sustainable urban infrastructure? Cities 2013, 31, 144-155. [CrossRef]

67. Ceron-Palma, I.; Sanyé-Mengual, E.; Oliver-Solà, J.; Montero, J.; Ponce-Caballero, C.; Rieradevall, J. Towards a green sustainable strategy for social neighbourhoods in Latin America: Case from social housing in Merida, Yucatan, Mexico. Habitat Int. 2013, 38, 47-56. [CrossRef]

68. Pearce, A.R.; Hastak, M.; Vanegas, J.A. A Decision support system for construction materials selection using sustainability as a criterion. In Proceedings of the 2012 Symposium on Simulation for Architecture and 
Urban Design (SimAUD '12), Society for Computer Simulation International, San Diego, CA, USA, 28-31 October 2012; pp. 1-5.

69. Lai, A.C.K.; Mui, K.W.; Wong, L.T.; Law, L.Y. An evaluation model for indoor environmental quality (IEQ) acceptance in residential buildings. Energy Build. 2009, 41, 930-936. [CrossRef]

70. Holden, M.; Scerri, A. More than this: Liveable Melbourne meets liveable Vancouver. Cities 2013, 31, 444-453. [CrossRef]

71. Zavrl, M.S.; Zarnic, R.; Selih, J. Multicriterial sustainability assessment of residential buildings. Technol. Econ. Dev. Eco. 2009, 15, 612-630. [CrossRef]

72. BPMSG AHP Online System. Available online: http://bpmsg.com/academic/ahp_calc.php (accessed on 5 May 2017).

73. Ceccato, V.; Lukyte, N. Safety and sustainability in a city in transition: The case of Vilnius, Lithuania. Cities 2011, 28, 83-94. [CrossRef]

74. Scolobig, A.; Lilliestam, J. Comparing approaches for the integration of stakeholder perspectives in environmental decision making. Resources 2016, 5, 37. [CrossRef]

(c) 2017 by the authors. Licensee MDPI, Basel, Switzerland. This article is an open access article distributed under the terms and conditions of the Creative Commons Attribution (CC BY) license (http://creativecommons.org/licenses/by/4.0/). 